\title{
In children, the addition of epinephrine modifies the pharmacokinetics of ropivacaine injected caudally
}

\author{
[Chez les enfants, l'addition d'épinéphrine modifie la pharmacocinétique de la \\ ropivacaïne administrée en injection caudale]
}

Luc J. Van Obbergh MD PhD, ${ }^{*}$ Fabienne A. Roelants MD, ${ }^{\star}$ Francis Veyckemans MD, ${ }^{\star}$ Roger K. Verbeeck PhD $\dagger$

Purpose: To describe the modification of the ropivacaine (R) pharmacokinetics produced by the addition of epinephrine (E).

Methods: After Institutional Review Board approval, I 8 ASA I boys received a caudal block (I $\left.\mathrm{mL} \cdot \mathrm{kg}^{-1}\right)$ with either plain $0.2 \% \mathrm{R}$ (Group E-) or with $0.2 \%$ R containing E (5 $\mu \mathrm{g} \cdot \mathrm{mL}^{-1}$; Group $\left.\mathrm{E}^{+}\right)$. Venous blood samples were taken at zero, 15, 30, 60, 90, 120, $180,240,420,720,1440$ min after caudal injection. Total R concentration in plasma was determined by high pressure liquid chromatography. Maximal concentration $\left(C_{\max }\right)$ and time to peak concentration $\left(T_{\max }\right)$ were obtained from the data, terminal half-life $\left(T_{1 / 2 z}\right)$, clearance $(\mathrm{Cl})$ and volume of distribution $(\mathrm{Vd})$ were estimated by a non-compartmental approach. Subsequently, in order to determine the absorption rate $(\mathrm{Ka})$ and to reduce to number of blood samples, 25 other children, receiving plain $\mathrm{R}$ and another group of 25 receiving the $E$ solution were studied using a population approach (NONMEM). A one compartment model with first order absorption was used. The effect of weight, age and $\mathrm{E}$ on $\mathrm{Cl}$, $\mathrm{Vd}$ and Ka was estimated.

Results: $C_{\max }$ was significantly lower in Group $E^{+}\left(0.93 \mathrm{mg} \cdot \mathrm{L}^{-1} \pm\right.$ $\left.0.29 \mathrm{vs} 0.61 \mathrm{mg} \cdot \mathrm{L}^{-1} \pm 0.28, P=0.05\right)$ and $T_{\max }$ occurred later ( $124 \mathrm{~min} \pm 53$ vs 47min $\pm 16, P=0.003$ ).

Weight was a significant covariate for $\mathrm{Cl}$ and $\mathrm{Vd}$ while $\mathrm{E}$ significantly slowed R Ka [Group I Ka $0.025 \mathrm{~min}^{-1}$ [coefficient of variation (CV) $21 \%$ ] vs $0.078 \mathrm{~min}^{-1}$ (CV 25\%) in Group II].

Conclusion: The addition of E significantly modifies the pharmacokinetics of $\mathrm{R}$ injected caudally.

Objectif: Décrire la modification de la pharmacocinétique de la ropivacaïne $(R)$ induite par l'addition d'épinéphrine (E).

Méthode : Ayant reçu l'approbation du Comité d'examen, nous avons administré un bloc caudal à 18 garçons d'état physique ASA I ( I mL $\left.\cdot \mathrm{kg}^{\prime}\right)$ avec, soit de la $R$ simple à 0,2 \% (Groupe E- ), soit de la $R$ à 0,2\% contenant de l'E (5 $\mu \mathrm{g} \cdot \mathrm{mL}^{-1}$; Group E+). Des échantillons de sang veineux ont été prélevés à zéro, 15, 30, 60, 90, 120, 180, 240, 420, 720, 1440 min après l'injection caudale. La concentration plasmatique totale de $R$ a été déterminée par chromatographie liquide haute pression. La concentration maximale $\left(C_{\text {max }}\right)$ et le temps d'atteindre la concentration maximale ( $\left.T_{\text {max }}\right)$ ont été obtenus des données; la demivie terminale $\left(T_{1 / 27}\right)$, la clairance $(C l)$ et le volume de distribution (Vd) ont été évalués par une méthode non compartimentale. Par la suite, dans le but de déterminer la vitesse d'absorption ( $K a$ ) et de réduire le nombre d'échantillons sanguins, 25 enfants, recevant de la $R$ simple et un autre groupe de 25, la solution d'E, ont été étudiés par une approche de population (NONMEM). Un modèle monocompartimental avec absorption du premier ordre a été utilisé. L'effet du poids, de l'âge et de l'E sur la Cl, le Vd et la Ka a été évalué.

Résultats : La $C_{\max }$ a été significativement plus faible dans le Groupe $E+\left(0,93 \mathrm{mg} \cdot \mathrm{L}^{-1} \pm 0,29 \mathrm{vs} 0,61 \mathrm{mg} \cdot \mathrm{L}^{-1} \pm 0,28, P=0,05\right)$ et le $T_{\max }$ a été plus tardif( $124 \mathrm{~min} \pm 53$ vs $47 \mathrm{~min} \pm 16, P=0,003)$. Le poids a été une covariable significative pour la Cl et le Vd tandis que l'E a significativement ralenti la Ka de la R [Groupe I, Ka 0,025 $\mathrm{min}^{-1}$ [coefficient de variation (CV) $21 \%$ ] vs 0,078 $\mathrm{min}^{-1}$ (CV $25 \%$ ) dans le Groupe II].

Conclusion : L'addition d'E modifie de façon significative la pharmacocinétique de la $R$ en injection caudale.

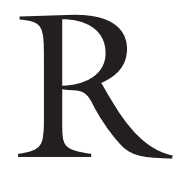
OPIVACAINE is an amide local anesthetic supplied as a pure enantiomer. This contributes to its decreased cardiotoxicity when compared to bupivacaine. ${ }^{1}$ Ropivacaine has already been used widely caudally to provide per and postoperative analgesia in infants and children undergoing lower abdominal surgery; 2,3 its pharmacokinetics

From the Department of Anesthesiology, ${ }^{*}$ and the School of Pharmacy, $†$ Université catholique de Louvain, Brussels, Belgium.

Address correspondence to: Prof L.J. Van Obbergh, Department of Anesthesiology, Cliniques St Luc, 101821 Av. Hippocrate, B1200

Brussels, Belgium. Phone: 3227641821; Fax: 3227643699; E-mail: vanobbergh@anes.ucl.ac.be

Financial support was provided by departmental and institutional resources.

Accepted for publication September 24, 2002.

Revision January 14, 2003.

Second revision accepted March 24, 2003. 
have also been studied in various conditions demonstrating that toxic levels are rarely reached if no intravascular injection occurs. ${ }^{4-6}$ However, as locoregional anesthesia is usually performed in children under general anesthesia or deep sedation, who are thus unable to report subjective signs of intravascular injection, strategies aiming at detecting early signs of accidental intravascular injection have been developed. ${ }^{7}$ The addition of epinephrine at the concentration of at least $2.5 \mu \mathrm{g} \cdot \mathrm{mL}^{-1}$ to the injected solution represents one of these. ${ }^{8}$ Moreover, it has recently been demonstrated that adding epinephrine $1 / 400000$ to bupivacaine prolongs its systemic absorption when injected caudally. ${ }^{9}$ The aim of the two studies presented here was to describe the modifications of the ropivacaine pharmacokinetics induced by the addition of epinephrine to the solution.

\section{Methods}

Part 1: two-stage pharmacokinetic study using a noncompartmental approach

After approval of the Ethics Committee and signed informed parental consent, 18 ASA I boys undergoing minor lower abdominal surgery were included in the study. No premedication was given, general anesthesia was induced and maintained with sevoflurane 3 to $4 \%$ in an air $/ \mathrm{O}_{2}$ mixture delivered with a modified Ayre's $\mathrm{T}$ piece (Mapleson D breathing circuit). Fresh gas flow was adjusted to avoid any rebreathing as shown by capnography. Monitoring consisted in end-tidal $\mathrm{CO}_{2}$ and sevoflurane, electrocardiogram (ECG), and pulse oximetry (AS3 monitor, Datex-Ohmeda, Helsinki, Finland). The children were allowed to breathe spontaneously through a face mask. An $i v$ line was inserted to provide $i v$ fluid maintenance according to Liu's formula ${ }^{10}$ and to allow blood sampling.

The children were randomly allocated to receive a caudal block $\left(1 \mathrm{~mL} \cdot \mathrm{kg}^{-1}\right)$ with either plain $0.2 \%$ ropivacaine (Group E-) or with $0.2 \%$ ropivacaine containing epinephrine freshly added to the solution in order to obtain a $1 / 200000$ concentration $\left(5 \mu \mathrm{g} \cdot \mathrm{mL}^{-1}\right.$; Group $\mathrm{E}^{+}$). The caudal block was performed as already described ${ }^{11}$ with a 22 -gauge $i v$ catheter after skin puncture with a larger needle to avoid any tissue coring. Careful aspiration was performed to exclude iv or intrathecal injection. The ECG waveform and the heart rate were monitored during the slow injection of the local anesthetic solution to detect any accidental iv injection: as the ECG changes caused in children by the in injection of ropivacaine are not yet described, any change in either the ECG waveform or heart rate was to be followed by the immediate interruption of the injection.

Venous blood samples were taken just before and $15,30,60,90,120,180,240,420,720,1440 \mathrm{~min}$ after the caudal injection. The collected blood was centrifuged and the plasma was kept frozen at $-20^{\circ} \mathrm{C}$ until further analysis.

Total ropivacaine concentration in plasma was determined by high pressure liquid chromatography (HPLC) following a method already described for other local anesthetic agents. ${ }^{12}$ This method is briefly summarized here. The plasma $(500 \mu \mathrm{L})$ containing the ropivacaine was mixed with $1 \mathrm{~mL}$ of $\mathrm{NaOH}$ and $4 \mathrm{~mL}$ of diethylic ether during $15 \mathrm{~min}$. This solution was then centrifuged at $3000 \mathrm{rpm}$ to separate the phases. The diethyl ether was then decanted with $250 \mu \mathrm{L} \mathrm{H}_{2} \mathrm{SO}_{4}(0.05 \mathrm{~N})$. The concentrations were determined by HPLC using a Lichrocart column 125-4 Superspher RP-selectB guarded by a precolumn. The mobile phase was a $\mathrm{KH}_{2} \mathrm{PO}_{4}$ buffer adjusted to a $\mathrm{pH}$ of 5.8 with $\mathrm{NaOH}(5 \mathrm{~N})$, pumped at $\mathrm{l} \mathrm{mL} \cdot \mathrm{min}^{-1}$. Detection was performed with a UV detector at $208 \mathrm{~nm}$ wavelength. Bupivacaine $(50 \mu \mathrm{L}$ of a $10 \mu \mathrm{g} \cdot \mathrm{mL}^{-1}$ solution) was used as internal standard. The quantification limits were $25 \mathrm{ng} \cdot \mathrm{mL}^{-1}$, with a precision of $6.7 \%$ at $50 \mathrm{ng} \cdot \mathrm{mL}^{-1}$ and $2.7 \%$ at $1000 \mathrm{ng} \cdot \mathrm{mL}^{-1}$.

Maximal plasma concentration $\left(\mathrm{C}_{\max }\right)$ and time to peak plasma concentration $\left(\mathrm{T}_{\max }\right)$ were obtained directly from the data. Terminal half-life $\left(\mathrm{T}_{1 / 2 \mathrm{z}}\right)$, clearance $(\mathrm{Cl})$ and volume of distribution $(\mathrm{Vd})$ were estimated by a non-compartmental approach as described by Gabrielsson ${ }^{13}$ using WinNonLin 1.5 (standard edition; Pharsight Co, Mountain View, CA, USA).

\section{Part 2: population analysis using NONMEM}

The effect of adding epinephrine on the absorption phase was studied using a population approach as it was considered unethical to increase the number of blood samples compatible with an adequate description of this phase when using a classical two-stage approach. Again after approval by the Ethics Committee and signed informed parental consent, 50 additional children were included in this second part of our study. Plain $0.2 \%$ ropivacaine was administered to half of them while the others received the same solution with epinephrine $(1 / 200000)$. The anesthetic technique, caudal block, surgical indications and the technique to measure the concentration of ropivacaine were similar to those described in part 1 .

Six to ten blood samples were taken from each patient: at least five were drawn randomly during the first 120 min after injection, as this was the time in which $\mathrm{T}_{\max }$ should occur as determined by the results presented in part 1 ; while the others were drawn at various times up to the 12th hr. We reduced the volume of the sample to $500 \mu \mathrm{L}$ and the number of samples to six in the infants to maintain the total volume of sampling below $\mathrm{l} \mathrm{mL} \cdot \mathrm{kg}^{-1}$. 
Population kinetics was then determined using NONMEM (version V). A one compartment linear model with first order absorption (ADVAN2) was found to fit our data. Subroutine TRANS 2 was used to calculate the following pharmacokinetic parameter (PK): $\mathrm{Cl}$ absorption half-time was calculated assuming that $\mathrm{T}_{1 / 2 \mathrm{abs}}=0.693 / \mathrm{Ka}$. The introduction of covariates [age, weight and scaling factor for $\mathrm{Ka}$ ] was made after visual inspection of the WRES $p s$ the covariate; the covariate was kept in the model when a decrease of the objective function of six $(P \sim 0.01)$ was observed. The different models introduced are summarized in Table II. Vd, $\mathrm{Cl}$ and absorption rate $(\mathrm{Ka})$ were estimated using the following exponential interpatient error model:

$\mathrm{PKj}=\mathrm{TVPK}^{*}(\exp \eta \mathrm{j})$

where $P K_{j}$ is the individual parameter for the $\mathrm{j}$ patient $(\mathrm{Vd}, \mathrm{Cl}, \mathrm{Ka})$, TVPK is the mean population parameter and $\eta j$ is the independently distributed variable with a mean of zero and a variance $\omega^{2}$ and an additive intrapatient error model:

$$
\mathrm{C}_{\mathrm{ij}}=\mathrm{C}_{\text {pred ij }}+\epsilon_{\mathrm{ij}}
$$

where $C_{i j}$ is the $i^{\text {th }}$ measured concentration for the $\mathrm{j}^{\text {th }}$ patient, $\mathrm{C}_{\text {pred ij }}$ is the predicted concentration and $\epsilon_{\mathrm{ij}}$ is the residual variability randomly distributed with zero mean and a variance $\sigma^{2}$.

Randomization was performed for both parts of the study with sealed envelopes to be opened after the inclusion of the child in the study. Using the data from the previous studies summarized in Table IV, a power analysis found that a sample size of nine patients per group would result in a power of $80 \%$ to detect a modification of $50 \%$ of both $\mathrm{C}_{\max }$ and $\mathrm{T}_{\max }$ when $P \leq$ 0.05 is considered as statistically significant.

Student's $t$ test was used in part 1 to perform between group comparisons. Results are mean \pm SD.

\section{Results}

None of the children studied developed any signs of toxicity or intravascular injection.

The results of the non-compartmental approach are summarized in Table I. The age, body weight and duration of surgery were similar in both groups. $\mathrm{C}_{\max }$ was significantly lowered by the addition of epinephrine, which also significantly delayed the $T_{\max }$ (Figure). Terminal half-life, $\mathrm{Cl}$ and $\mathrm{Vd}$ were not modified by the addition of epinephrine.

Children included in the population analysis were aged from one day to 48 months with a weight ranging from 2.8 to $18 \mathrm{~kg}$. The minimal objective function and the inclusion of the covariate in the model are found in Table II. Introducing the weight divided by
TABLE I Results of the first part of the study

\begin{tabular}{llll}
\hline & E- Group & E+ Group & $P$ \\
\hline$n$ & 9 & 9 & \\
Age (months) & $31 \pm 9$ & $38 \pm 11$ & $\mathrm{NS}$ \\
Weight $(\mathrm{kg})$ & $14 \pm 1.18$ & $14 \pm 2.21$ & $\mathrm{NS}$ \\
$\mathrm{C}_{\max }\left(\mathrm{mg} \cdot \mathrm{L}^{-1}\right)$ & $0.93 \pm 0.29$ & $0.61 \pm 0.28$ & 0.05 \\
$\mathrm{~T}_{\max }(\mathrm{min})$ & $47 \pm 16$ & $124 \pm 53$ & 0.003 \\
$\mathrm{~T}_{1 / 2 \mathrm{z}}(\mathrm{hr})$ & $4.32 \pm 2.77$ & $4.46 \pm 1.26$ & $\mathrm{NS}$ \\
$\mathrm{Cl}\left(\mathrm{mL} \cdot \mathrm{kg}^{-1} \cdot \mathrm{hr}^{-1}\right)$ & $406 \pm 173$ & $519 \pm 271$ & $\mathrm{NS}$ \\
$\mathrm{Vd}\left(\mathrm{L} \cdot \mathrm{kg}^{-1}\right)$ & $2.23 \pm 0.9$ & $3.49 \pm 2.7$ & $\mathrm{NS}$ \\
\hline
\end{tabular}

E - Group $=$ children receiving plain ropivacaine $; \mathrm{E}+$ Group $=$ children receiving a ropicavaine plus epinephrine; $\mathrm{C}_{\max }=$ maximal plasma concentration; $\mathrm{T}_{\max }=$ time to $\mathrm{C}_{\max } ; \mathrm{T}_{1 / 2 \mathrm{z}}=$ terminal halflife; $\mathrm{Cl}=$ clearance; $\mathrm{Vd}=$ distribution volume; $\mathrm{NS}=$ difference not statistically significant. Data are expressed as mean \pm SD.

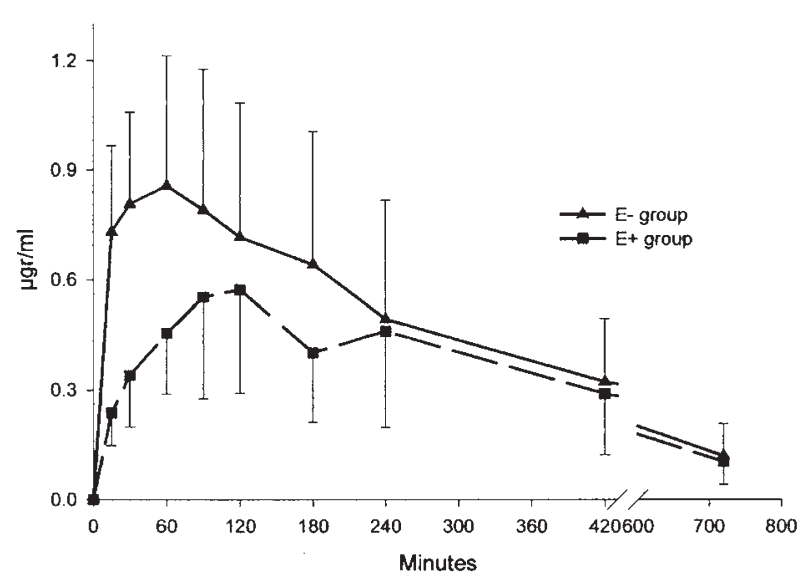

FIGURE Concentration $v s$ time curves of children receiving caudal $0.2 \%$ ropivacaine $\left(2 \mathrm{mg} \cdot \mathrm{kg}^{-1}\right)$ either with ( $\mathrm{E}^{+}$Group) or without epinephrine (E-Group; mean $\pm \mathrm{SD}$ ).

the median value of our population $(12 \mathrm{~kg})$ into the model modified significantly the estimated values of both $\mathrm{Cl}$ and $\mathrm{Vd}$ but not Ka; however, age divided by the median age (34 months) had no effect on the fitting for $\mathrm{Cl}$, $\mathrm{Vd}$ or $\mathrm{Ka}$. The final introduction of a factor scaling for the presence of epinephrine $(\mathrm{ADR}=1)$ again significantly improved the estimation by modifying the final value of Ka. The results of the final model described by NONMEM are summarized in Table III. The estimated absorption half-time of plain ropivacaine was nine minutes while the addition of epinephrine increased it up to $27 \mathrm{~min}$. 
TABLE II Models used for the population study

\begin{tabular}{llll}
\hline Model & Equation & MOF & $\begin{array}{l}\text { Kept in } \\
\text { model }\end{array}$ \\
\hline Basic & $\mathrm{V}=\Phi 2$ & -225 & \\
& $\mathrm{CL}=\Phi 1$ & & \\
& $\mathrm{KA}=\Phi 3$ & & \\
Weight & $\mathrm{V}=\Phi 2^{*}(\text { weight } / 12)^{\Phi 6}$ & -254 & Yes \\
& $\mathrm{CL}=\Phi 1^{*}(\text { weight } / 12)^{\Phi 5}$ & & \\
& $\mathrm{KA}=\Phi 3$ & \\
Age & $\mathrm{V}=\Phi 2^{*}(\mathrm{AGE} / 34)^{\Phi 6}$ & -195 & No \\
& $\mathrm{CL}=\Phi 1^{*}(\mathrm{AGE} / 34)^{\Phi 5}$ & & \\
& $\mathrm{KA}=\Phi 3$ & \\
Final & $\mathrm{V}=\Phi 2^{*}(\text { weight } / 12)^{\Phi 6}$ & -292 & Yes \\
& $\mathrm{CL}=\Phi 1^{*}(\text { weight } / 12)^{\Phi 5}$ & & \\
& if $\mathrm{ADR}=1 \mathrm{KA}=\Phi 3$ & & \\
& Else $\mathrm{KA}=\Phi 4$ & & \\
\hline
\end{tabular}

$\mathrm{MOF}=$ minimal objective function; $\mathrm{Vd}=$ volume of distribution; $\mathrm{CL}=$ clearance $\mathrm{KA}=$ absorption rate. The factors 12 and 34 have been selected as they represent respectively the median weight $(\mathrm{kg})$ and age (months) of the children included in part $2 . \mathrm{ADR}=$ one means that the children are receiving an epinephrine containing solution.

TABLE III Parameters estimated by NONMEM in the final model

\begin{tabular}{lll}
\hline Parameter & Estimate & $C V(\%)$ \\
\hline$\Phi 1\left(\mathrm{~mL} \cdot \mathrm{min}^{-1}\right)$ & 91 & 45 \\
$\Phi 2(\mathrm{~mL})$ & 32500 & 35 \\
$\Phi 3\left(\mathrm{~min}^{-1}\right)$ & 0.025 & 21 \\
$\Phi 4\left(\mathrm{~min}^{-1}\right)$ & 0.078 & 25 \\
$\Phi 5$ & 1.35 & \\
$\Phi 6$ & 0.707 & \\
\hline
\end{tabular}

$\Phi 1$ = clearance; $\Phi 2$ = distribution volume; $\Phi 3$ = absorption coefficient in Group E+; $\Phi ? 4$ = absorption coefficient in Group E-; CV $=$ coefficient of variation.

\section{Discussion}

This study shows that the addition of epinephrine to ropivacaine injected caudally modifies its pharmacokinetics. We found that adding a vasoconstrictor decreases the $\mathrm{C}_{\max }$ of ropivacaine and delays its absorption from the epidural space as shown by the later occurrence of $\mathrm{T}_{\max }$ and the longer absorption half-time.

Bupivacaine has been widely used to provide caudal analgesia in children. Although toxic concentrations are rarely obtained when a maximum of $1 \mathrm{~mL} \cdot \mathrm{kg}^{-1}$ of $0.25 \%$ bupivacaine is used, some authors have recommended that epinephrine should be added to facilitate the detection of intravascular injection as this remains a risk for acute intoxication. ${ }^{14}$ It has recently been shown that the addition of epinephrine $(1 / 400000)$ to a $0.25 \%$ bupivacaine solution did not modify the $\mathrm{C}_{\max }$ nor the $\mathrm{T}_{\text {max }}$ : however the plasma concentrations measured at 360 min were significantly higher when a vasoconstrictor was added and the authors therefore concluded that epinephrine prolonged the systemic absorption of bupivacaine injected into the caudal space. ${ }^{9}$

Our results with ropivacaine, however, show more noticeable changes. The greater effects of epinephrine on ropivacaine may be due to the fact that ropivacaine is more liposoluble than bupivacaine and has some intrinsic vasoactivity. The slower absorption of ropivacaine from the caudal space when compared to bupivacaine has been described recently. ${ }^{15}$ Its absorption from the epidural space is slow and has been described as biphasic; this is related to the high partitioning of ropivacaine into fat. ${ }^{16}$

Although the $\mathrm{T}_{\max }$ observed in the epinephrinegroup was similar to those obtained in other studies (Table IV), we found a greater $\mathrm{C}_{\max }$. However, there is a large variation of the latter parameter in each of those previous studies: this may also explain why the difference in ropivacaine $\mathrm{C}_{\max }$ we measured with or without the addition epinephrine was less significant in our study $(P=0.05)$ than the modification observed for $\mathrm{T}_{\max }$. This is in accordance with the bupivacaine study where the main effect of adding epinephrine was mainly a longer absorption phase. ${ }^{9}$

The results we found for $\mathrm{Vd}$ and $\mathrm{Cl}$ are similar in both parts of our study and are comparable to those found in the two studies describing these parameters. ${ }^{17,18}$

The Ka of plain ropivacaine calculated by the population approach used in part two is similar to that found by Hansen et al. This parameter was not influenced by weight or age confirming the previously mentioned study; ${ }^{18}$ although it has been described that the addition of epinephrine to bupivacaine significantly prolonged the duration of the block and that this was greatest in the younger children. ${ }^{19} \mathrm{We}$ found that weight was a significant covariate for $\mathrm{Vd}$ and $\mathrm{Cl}$ confirming the results of Lonnqvist et al. who described that age did not modify these parameters and that weight was probably the best variable to adjust dosage. ${ }^{5}$ However, Hansen et al. were able to correlate $\mathrm{Cl}$ with age but their population was younger than ours: these authors indeed studied very young infants and their results are probably linked to the immaturity of the hepatic metabolic pathways in these patients. They also found that the percentage of free ropivacaine was a good covariate for $\mathrm{Cl}$ in infants. ${ }^{18}$ We only determined total ropivacaine concentrations as its binding to plasma proteins or red cells should not be influenced by the addition of epinephrine and because the determination of unbound ropivacaine would require larger blood samples and increase the cost of the study. 
TABLE IV Comparison of the ropivacaine pharmacokinetic parameters estimated by this study with those issued from other pediatric studies

\begin{tabular}{|c|c|c|c|c|c|c|c|c|c|}
\hline & A & B & $\mathrm{C}$ & $\mathrm{D}$ & $\mathrm{E}$ & $\mathrm{F}$ & $\mathrm{G}$ & $\mathrm{H}$ & I \\
\hline Dose $\left(\mathrm{mg} \cdot \mathrm{kg}^{-1}\right)$ & 2 (plain) & $2\left(\mathrm{E}^{+}\right)$ & 2 (plain) & 2 (plain) & 2.5 (plain) & 2 (plain) & 2 (plain) & 2 (plain) & 2 (plain) \\
\hline Age (months) & 31 & 38 & 48 & 56 & 25 & 96 & 8 & $2.6(\mathrm{I}) 35(\mathrm{~T})$ & 32 \\
\hline $\mathrm{T}_{\max }(\min )$ & 47 & 124 & $\begin{array}{l}62 \\
{[16-125]}\end{array}$ & $\begin{array}{l}55 \\
{[10-120]}\end{array}$ & $\begin{array}{l}75 \\
{[20-125]}\end{array}$ & $\begin{array}{l}53 \\
{[30-240]}\end{array}$ & $\mathrm{NA}$ & $\begin{array}{l}60[15-90](\mathrm{I}) \\
52.5[30-120](\mathrm{T})\end{array}$ & 60 \\
\hline $\mathrm{C}_{\max }\left(\mathrm{mg} \cdot \mathrm{L}^{-1}\right)$ & 0.930 & 0.610 & $\begin{array}{l}0.470 \\
{[0.32-0.75]}\end{array}$ & $\begin{array}{l}0.846 \\
{[0.538-1.22]}\end{array}$ & $\begin{array}{l}0.799 \\
{[707-1044]}\end{array}$ & $\begin{array}{l}0.640 \\
{[0.380-1.28]}\end{array}$ & $\begin{array}{l}0.748 \\
{[0.425-1.579]}\end{array}$ & $\begin{array}{l}0.73(0.27)(\mathrm{I}) \\
0.49(0.21)(\mathrm{T})\end{array}$ & $1.03(0.4)$ \\
\hline $\mathrm{Vd}\left({\left.\mathrm{L} \cdot \mathrm{kg}^{-1}\right)}\right.$ & 2.23 & 3.49 & NA & NA & 2.4 & $\mathrm{NA}$ & 2.12 & NA & NA \\
\hline $\mathrm{Cl}\left(\mathrm{mL} \cdot \mathrm{kg}^{-1} \cdot \mathrm{hr}^{-1}\right)$ & 406 & 519 & NA & NA & 456 & NA & 310 & NA & NA \\
\hline $\mathrm{Ka}\left(\min ^{-1}\right)$ & 0.025 & 0.078 & NA & NA & NA & NA & 0.026 & NA & NA \\
\hline
\end{tabular}

$\mathrm{A}$ and $\mathrm{B}=$ present study; $\mathrm{C}=$ Lonqvist et al. ${ }^{5} \mathrm{D}=$ Ala Kokko et al. $;{ }^{4} \mathrm{E}=$ Habre et al. $;{ }^{17} \mathrm{~F}=$ Bosenberg et al. $;^{6} \mathrm{G}=\mathrm{Hansen}$ et al.; $;^{18} \mathrm{H}=$ Wulf et al. $(\mathrm{I}=$ infants, $\mathrm{T}=$ toddlers $) ;{ }^{21} \mathrm{I}=\mathrm{Luz}$ et al. ${ }^{22} \mathrm{C}_{\max }=$ maximal plasma concentration; $\mathrm{T}_{\max }=$ time to $\mathrm{C}_{\max } ; \mathrm{Cl}=$ clearance; $\mathrm{Vd}=$ distribution volume; plain = plain ropivacaine $\mathrm{E}^{+}=$ropivacaine + epinephrine; $\mathrm{NA}=$ results not available .

Finally, as many other teams worldwide, we routinely use a 22 -gauge iv cannula to perform a caudal block in infants and children. ${ }^{11}$ We acknowledge that the use of a styletted needle, such as a lumbar puncture needle, a Crawford epidural needle or a special "caudal" needle, is recommended by many authors. However, it has been shown that the use of a styletted needle does not reduce the risk of tissue coring into the sacral epidural space providing that a small nick in the skin is made prior to insertion of the $i v$ cannula. ${ }^{20}$ Moreover, using a small $i v$ cannula instead of a needle reduces the risk of intraosseus penetration and injection as well of displacement into a vessel or subarachnoid space during the injection. This should however not modify the pharmacokinetics of the drug injected caudally.

In conclusion, we have described the pharmacokinetic modifications occurring when epinephrine 5 $\mu \mathrm{g} \cdot \mathrm{mL}^{-1}$ is added to ropivacaine injected caudally. Absorption is prolonged and $\mathrm{T}_{\max }$ occurs significantly later; $\mathrm{C}_{\max }$ is also decreased but to a lesser extent. Further studies are required to determine whether adding epinephrine to ropivacaine results in a prolonged duration of action and whether it effectively helps in detecting an $i v$ injection.

\section{References}

1 Markham A, Faulds D. Ropivacaine. A review of its pharmacology and therapeutic use in regional anaesthesia. Drugs 1996; 52: 429-49.

2 Van Obbergh LJ, Veyckemans F. Caudal and epidural anaesthesia with ropivacaine in children. Acta Anaesthesiol Belg 2000; 51: 123-6.

3 Khalil S, Campos C, Farag AM, Vije H, Ritchey M, Chuang A. Caudal block in children. Ropivacaine com- pared with bupivacaine. Anesthesiology 1999; 91: 1279-84.

4 Ala-Kokko TI, Partanen J, Karinen A, Kiviluoma K, Alabubta S. Pharmacokinetics of $0.2 \%$ ropivacaine and $0.2 \%$ bupivacaine following caudal blocks in children. Acta Anaesthesiol Scand 2000; 44: 1099-102.

5 Lonnqvist PA, Westrin P, Larsson BA, et al. Ropivacaine pharmacokinetics after caudal block in 1-8 year old children. Br J Anaesth 2000; 85: 506-11.

6 Bosenberg AT, Thomas J, Lopez T, Huledal G, Jeppsson $L$, Larsson LE. Plasma concentrations of ropivacaine following a single-shot caudal block of 1, 2 or 3 $\mathrm{mg} / \mathrm{kg}$ in children. Acta Anaesthesiol Scand 2001; 45: 1276-80.

7 Bosenberg AT, Ivani G. Regional anaesthesia - children are different (Editorial). Paediatr Anaesth 1998; 8: 447-50.

8 Rowney DA, Doyle E. Epidural and subarachnoid blockade in children. Anaesthesia 1998; 53: 980-1001.

9 Hansen TG, Morton NS, Cullen PM, Watson DG. Plasma concentrations and pharmacokinetics of bupivacaine with and without adrenaline following caudal anaesthesia in infants. Acta Anaesthesiol Scand 2001; 45: 42-7.

10 Liu L. Fluid management. In: Ryan JF, Coté CJ, Todres ID, Goudsouzian N (Eds.). A Practice of Anesthesia for Infants and Children. Philadelphia: WB Saunders; 1993: 171-83.

11 Veyckemans F, Van Obbergh L, Gouverneur JM. Lessons from 1100 pediatric caudal blockade in a teaching hospital. Reg Anesth 1992; 17: 119-25.

12 Sattler A, Kramer I, Jage J, Vrana S, Kleemann PP, Dick $W$. Development of a HPLC-system for quantitative measurement of lidocaine and bupivacaine in 
patients plasma during postoperative epidural pain therapy. Pharmazie 1995; 50: 741-5.

13 Gabrielsson J, Weiner D. Pharmacokinetic concepts. In: Gabrielsson J, Weiner D (Eds.). Pharmacokinetic and Pharmacodynamic Data Analysis: Concepts \& Applications, 3rd ed. Stockholm: Swedish Pharmaceutical press; 2000: 45-174.

$14 \mathrm{McGown} R$ R. Caudal analgesia in children. Anaesthesia 1982; 37: 806-18.

15 Karmakar MJ, Aun CS, Wong EL, Wong AS, Chan SK, Yeung $C K$. Ropivacaine undergoes slower systemic absorption from the caudal epidural space in children than bupivacaine. Anesth Analg 2002; 94: 259-65.

16 Thomas JM, Schug SA. Recent advance in the pharmacokinetics of local anaesthetics. Clin Pharmacokinet 1999; 36: 67-83.

17 Habre W, Bergesio R, Johnson C, Hackett P, Joyce D, Sims $C$. Pharmacokinetics of ropivacaine following caudal analgesia in children. Paediatr Anaesth 2000; 10: 143-7.

18 Hansen TG, Ilett KF, Reid C, Lim SI, Hackett P, Bergesio $R$. Caudal ropivacaine in infants. Population pharmacokinetics and plasma concentrations. Anesthesiology 2001; 94: 579-84.

19 Warner MA, Kunkel SE, Offord KO, Atchison SR, Dawson $B$. The effects of age, epinephrine, and operative site on duration of caudal analgesia in pediatric patients. Anesth Analg 1987; 66: 995-8.

20 Goldschneider K, Brandom B. The incidence of tissue coring during the performance of caudal injection in children. Reg Anesth Pain Med 1999; 24: 553-6.

21 Wulf H, Peters C, Behnke H. The pharmacokinetics of caudal ropivacaine $0.2 \%$ in children. Anaesthesia 2000; 55: 757-60.

22 Luz G, Innerhofer P, Haussler B, Oswald E, Salner E, Sparr H. Comparaison of ropivacaine $0.1 \%$ and $0.2 \%$ with bupivacaine $0.2 \%$ for single-shot caudal anaesthesia in children. Paediatr Anaesth 2000; 10: 499-504. 